\title{
Editorial Introduction
}

I would like to start the text by apologizing for not responding to emails, as I am away due to health problems and I have not had support to keep the system up to date. I take this opportunity to say that from today I intend to put the entire system in order and updated.

This issue of the Independent Journal of Management \& production (IJM\&P) features a selection of articles submitted and revised until April 2019. Observe the works are the fruit of research and publications of undergraduate, postgraduate and entrepreneurs.

It is important to mention that all the works are showed without any kind of payment. All of them are published free from payments or taxes.

The publication also counts on the work of researchers from various parts of the world, which have undergone a process of peer review.

As chief editor of $\mathbf{I J M} \boldsymbol{M} \boldsymbol{P}$, I am indebted to all members of the editorial board and reviewers, which contributed to achieve a very decent job during the evaluation and revision. Moreover, that they have contributed to the Journal in recognition of the international scientific community.

In addition, with all the authors, who trusted the results of their research and publications to the scrutiny of editors and reviewers who are part of our Journal.

In the period from January, 01 to September, 30 2021, the journal was accessed by approximately 22,507 users, of approximately 3,523 cities and 176 countries, in the Figure 1 is presented the map mundi, in which can be observed the countries of where was originating the access (GOOGLE, 2021). 


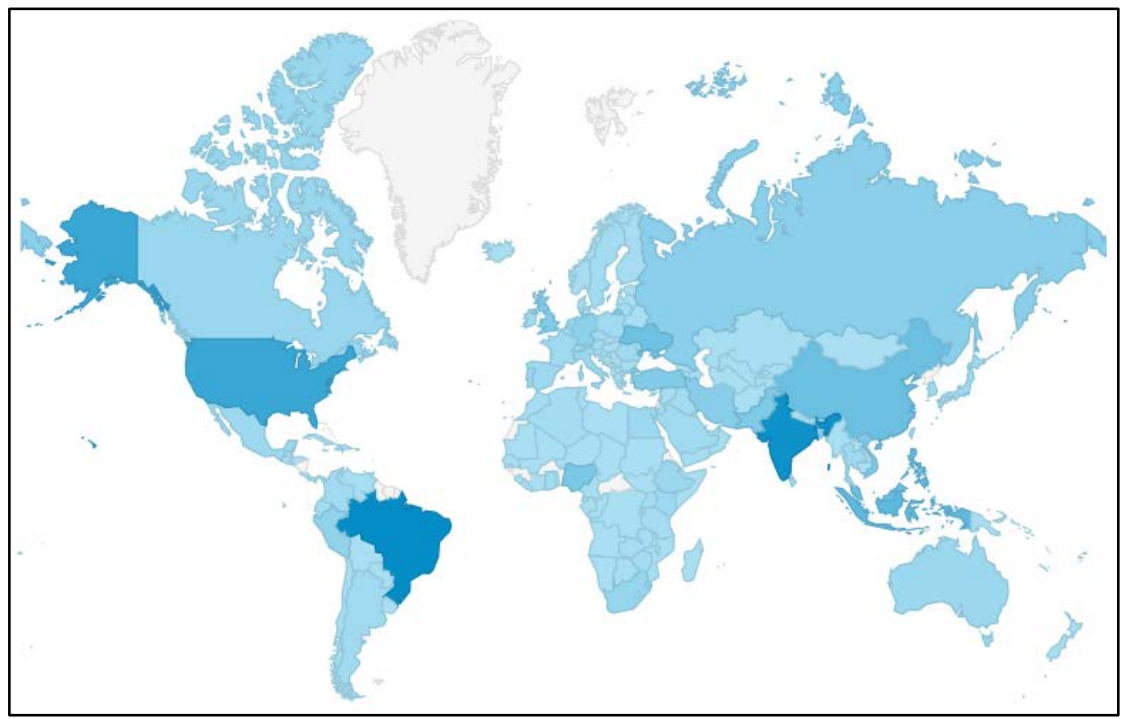

Figure 1: Countries that have accessed the journal Source: Google analytics (2021) ${ }^{1}$

The Table 1 shows the preview data and journal access, since its creation in 2010.

Table 1: views by volume/number

\begin{tabular}{|r|rrr|rr|r|}
\hline Year & \multicolumn{1}{|l|}{ Country } & \multicolumn{1}{l|}{ Cities } & \multicolumn{1}{c|}{ Access } & \multicolumn{1}{l|}{ Users } & \multicolumn{1}{l|}{ Viewers } \\
\hline \hline 2010 & 25 & 75 & 340 & 181 & 5,474 \\
\hline \hline 2011 & 75 & 343 & 1,510 & 1,024 & 12,942 \\
\hline 2012 & 83 & 444 & 2,187 & 1,406 & 15,499 \\
\hline \hline 2013 & 118 & 1,208 & 11,946 & 6,006 & 71,264 \\
\hline \hline 2014 & 146 & 1,978 & 17,440 & 10,503 & 68,340 \\
\hline \hline 2015 & 147 & 2,307 & 23,017 & 14,460 & 96,735 \\
\hline \hline 2016 & 162 & 2,911 & 26,654 & 17,847 & 112,928 \\
\hline \hline 2017 & 184 & 4,078 & 37,171 & 27,129 & 109,535 \\
\hline \hline 2018 & 190 & 5,220 & 57,157 & 44,400 & 187,729 \\
\hline \hline 2019 & 197 & 5,534 & 78,195 & 60,907 & 218,628 \\
\hline \hline 2020 & 194 & 6,020 & 78,149 & 58,378 & 279,287 \\
\hline \hline 2021 & 178 & 4,009 & 46,097 & 28,861 & 131,639 \\
\hline
\end{tabular}

In Figures 2, 3, 4, 5, 6, 7, 8, 9 and 10 is shown a graph of the amount of hits that the journal received between January 1, 2014 and July 31, 2021; these data are based on information provided by the Google analytics.

\footnotetext{
${ }^{1}$ Google Analytics (2020). Google Analytics: IJM\&P. Avaliable in: https://analytics.google.com/analytics/web/\#/report/visitorsgeo/a4556113w8782567p9154049/_u.date00=20200101\&_u.date01=20201130\&tabControl.tabId=geo\&geosegmentExplorer.segmentId=analytics.country/. Access: 08/01/2021.
} 
INDEPENDENT JOURNAL OF MANAGEMENT \& PRODUCTION (IJM\&P)

http://www.ijmp.jor.br

v. 12, n. 7, September-October 2021

ISSN: 2236-269X

DOI: 10.14807/ijmp.v12i7.1452

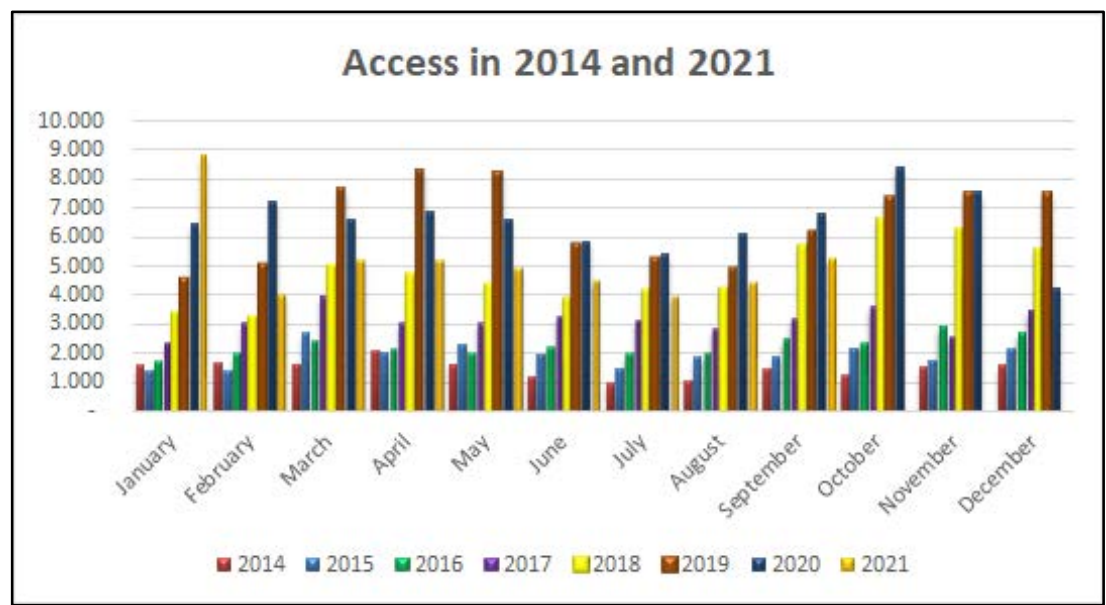

Figure 2: amount of hits between 2014 and 2021

The Figure 3 shows the comparison of the number of cities, around the world, that have accessed the journal.

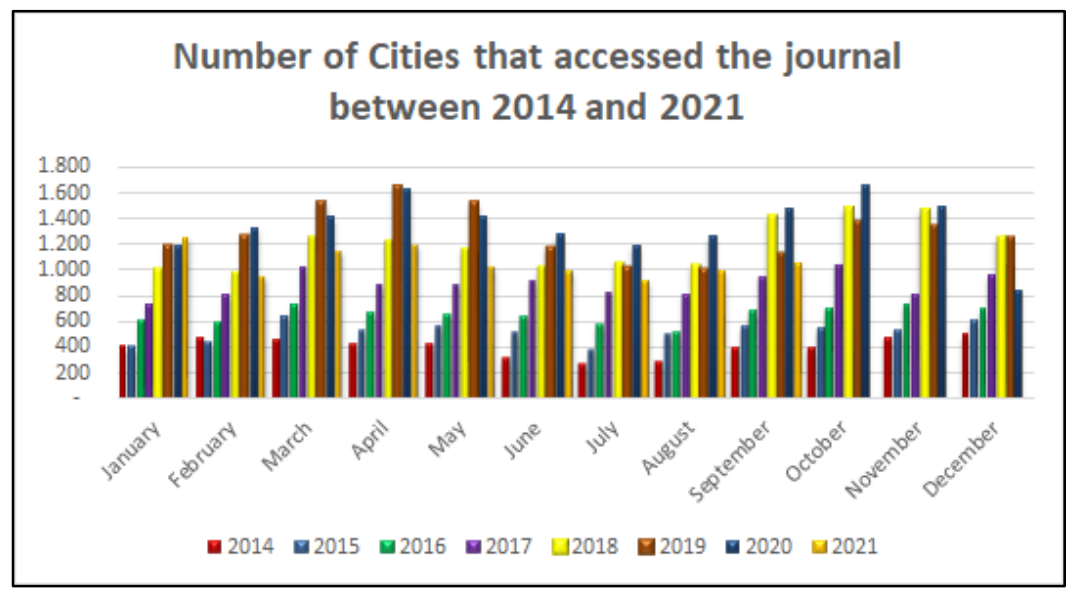

Figure 3: Amount of cities between 2014 and 2021

The Figure 4 shows the averages of views on the journal in the period between the years of 2014 and 2021.

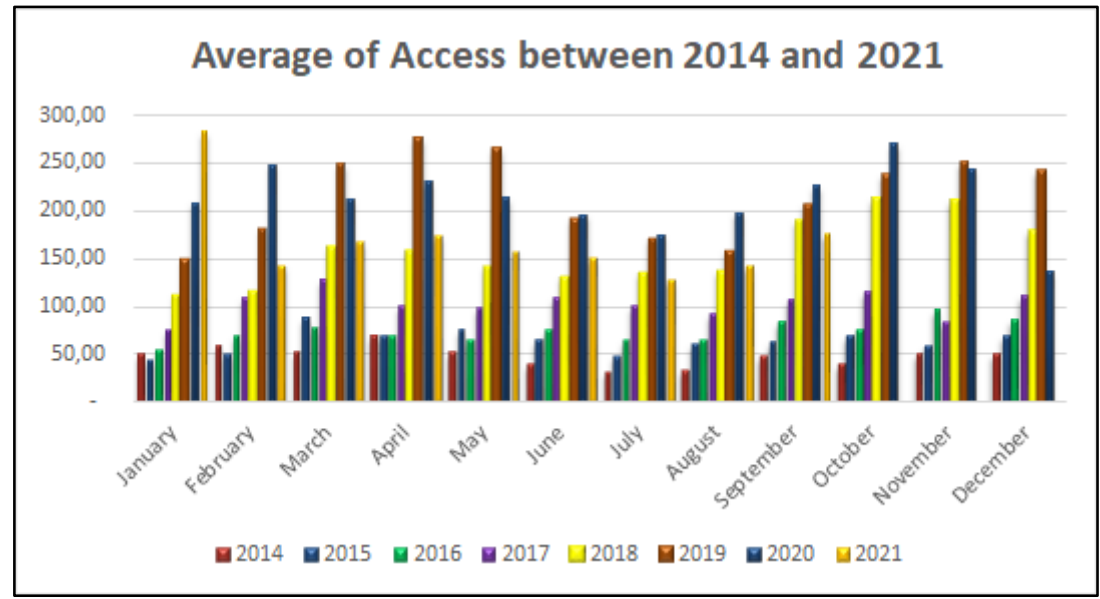

Figure 4: Amount of average between 2014 and 2021 
INDEPENDENT JOURNAL OF MANAGEMENT \& PRODUCTION (IJM\&P)

http://www.ijmp.jor.br

v. 12, n. 7, September-October 2021

ISSN: 2236-269X

DOI: 10.14807/ijmp.v12i7.1452

The Figure 5 shows the comparison of the number of countries, around the world, that have accessed the journal.

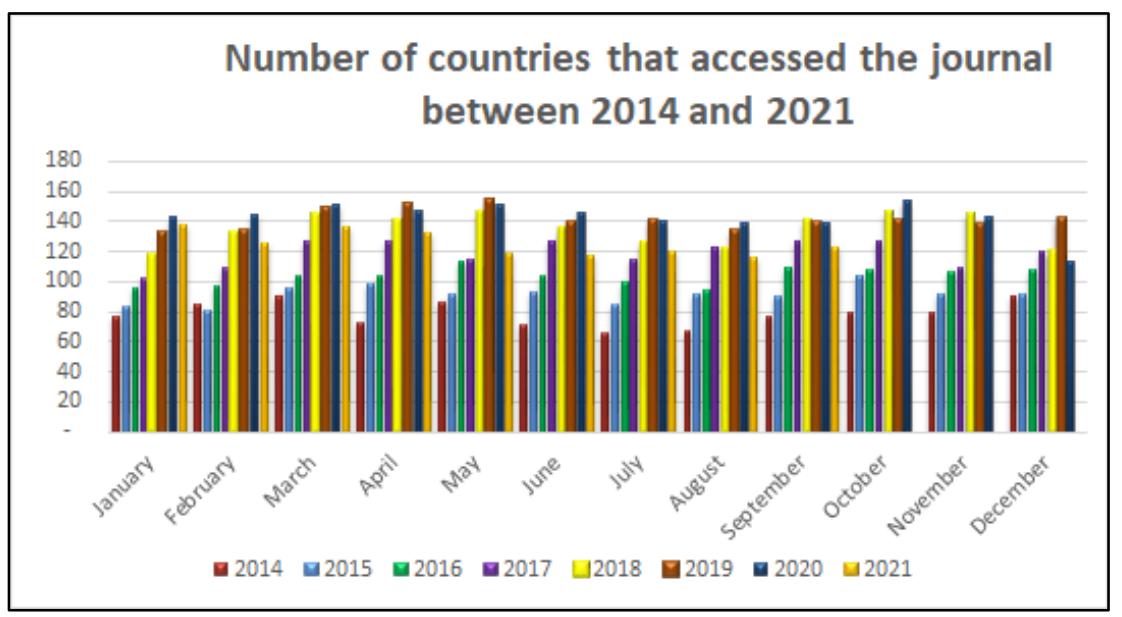

Figure 5: Amount of countries between 2014 and 2021

The Figure 6 shows the comparison of the number of users, around the world, that have accessed the journal.

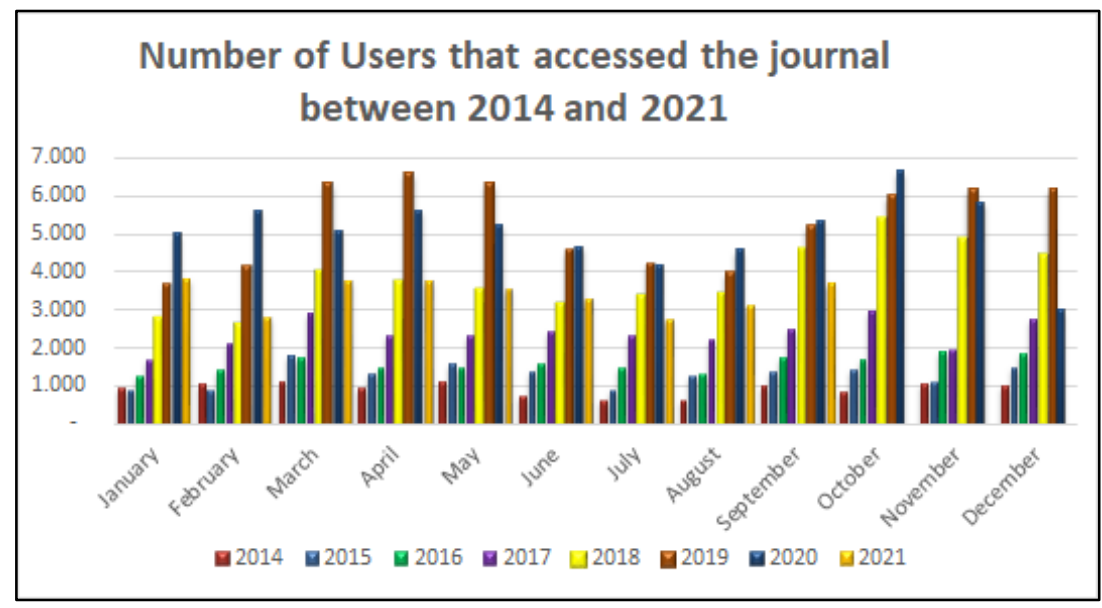

Figure 6: Amount of users between 2014 and 2021

The Figure 7 shows the comparison of the number of viewers, around the world, that have accessed the journal. 
INDEPENDENT JOURNAL OF MANAGEMENT \& PRODUCTION (IJM\&P)

http://www.ijmp.jor.br

v. 12, n. 7, September-October 2021

ISSN: 2236-269X

DOI: 10.14807/ijmp.v12i7.1452

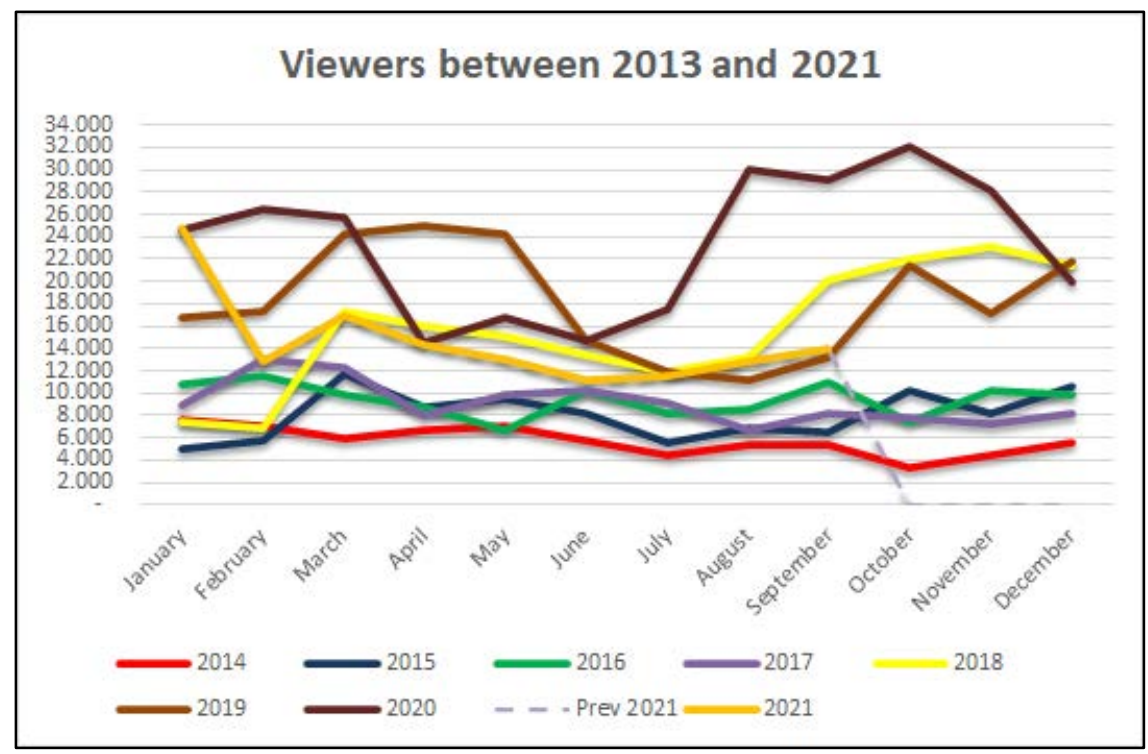

Figure 7: Amount of Viewers between 2013 and 2021

Figure 8 shows the overall evolution accumulated in the 12 months, as well as the visualizations between the years of 2013 and 2021 and that can be compared with Figure 7.

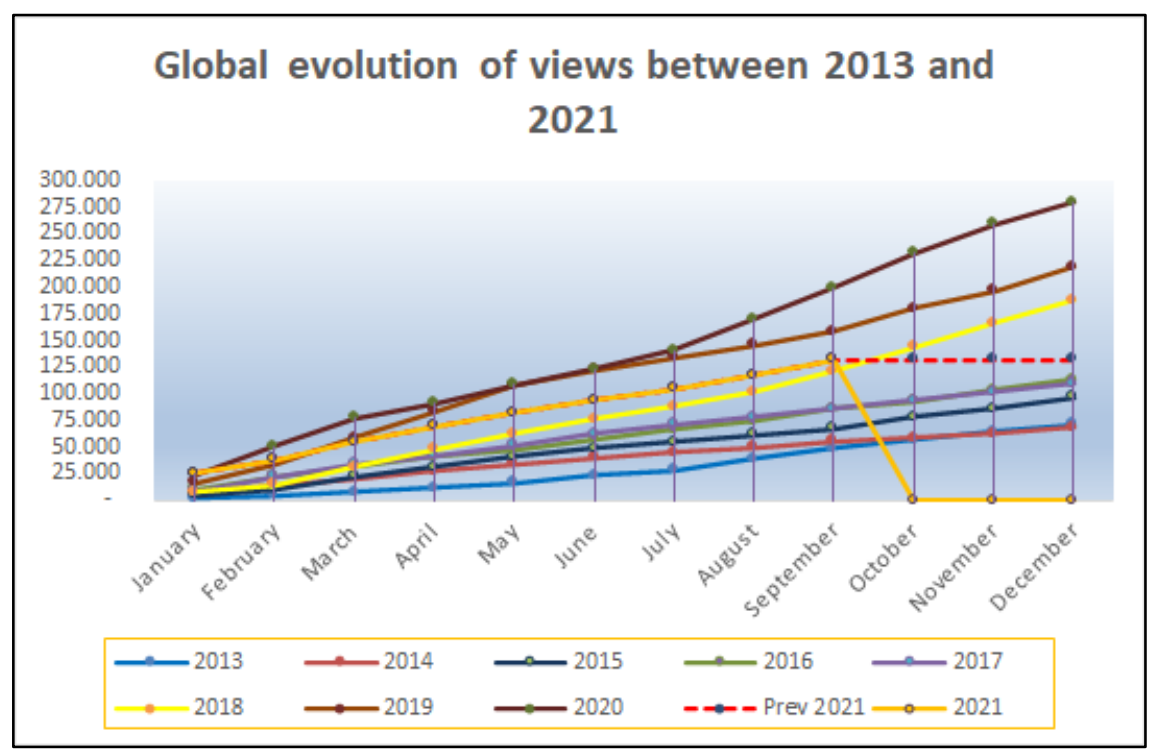

Figure 8: Global evolution of views between 2013 and 2021

Figure 9 shows the evolutionary chart of resolutions address the articles registered in CrossRef since 2014, which is based on monthly report. This graph can be seen the evolution of the journal has achieved. 
INDEPENDENT JOURNAL OF MANAGEMENT \& PRODUCTION (IJM\&P)

http://www.ijmp.jor.br

V. 12, n. 7, September-October 2021

ISSN: 2236-269X

DOI: 10.14807/ijmp.v12i7.1452

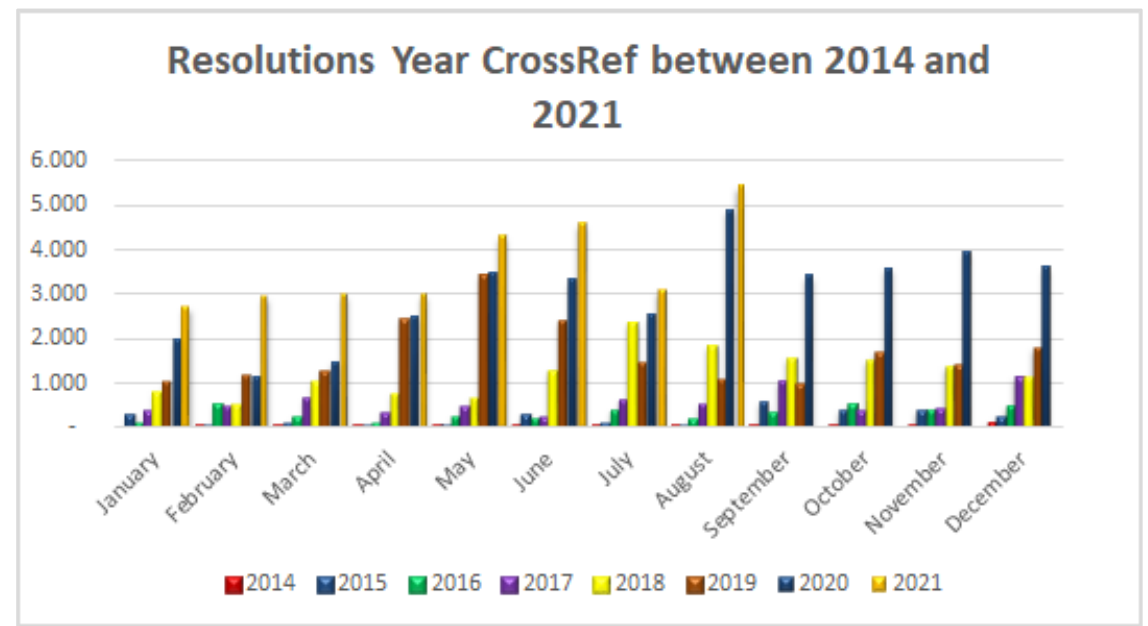

Figure 9: Resolution Report for prefix 10.14807 from between 2014 and 2021

From figure 10, data extracted from Microsoft Academic and Web of science will be presented, presenting the development of the journal, in quantities of citations.

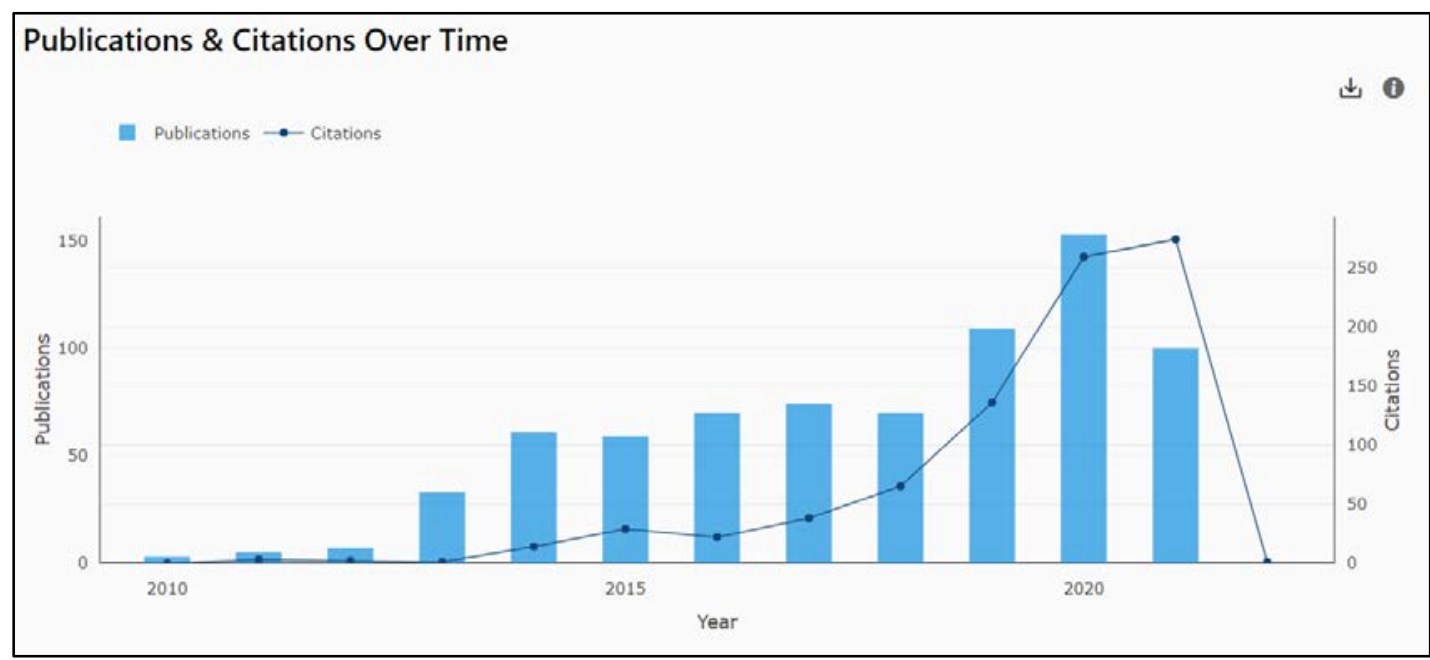

Figure 10: Publications \& Citations Over Time Source: Microsoft Academic (2021) ${ }^{2}$

Figure 11 shows the data on the number of citations and the evolution that the journal has been obtaining since 2015, and in this data it is also possible to observe the number of selfcitations and discounting the self-citations.

\footnotetext{
${ }^{2}$ Microsoft Academic (2021). Publications \& Citations Over Time: Independent Journal of Management \& Production. Avaliable in:

https://academic.microsoft.com/journal/2739372441/publication/search?q=Independent\%20Journal\%20of\%20M anagement\%20\%26\%20Production\&qe=And(Composite(J.JId\%3D2739372441)\%2CTy\%3D\%270\%27)\&f=\&o rderBy=3. Access in: 08/01/2021.
} 
INDEPENDENT JOURNAL OF MANAGEMENT \& PRODUCTION (IJM\&P)

http://www.ijmp.jor.br

v. 12, n. 7, September-October 2021

ISSN: 2236-269X

DOI: 10.14807/ijmp.v12i7.1452

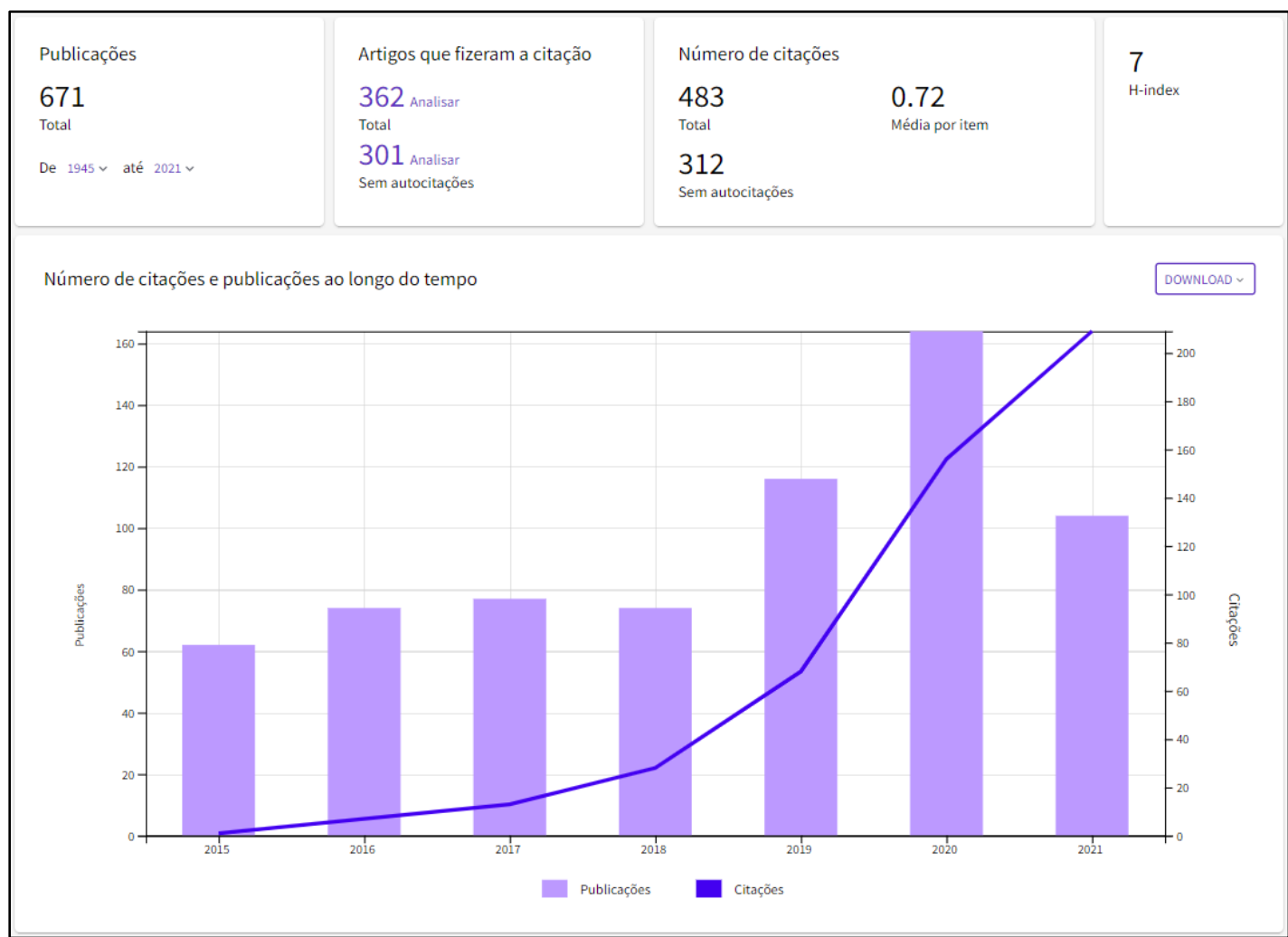

Figure 11: Sum of Times Cited per Year Source: Web of Science (2021) ${ }^{3}$

Figure 12 shows, in tree map format, the number of citations per country, which shows that the journal has been gaining visibility in Brazil and worldwide

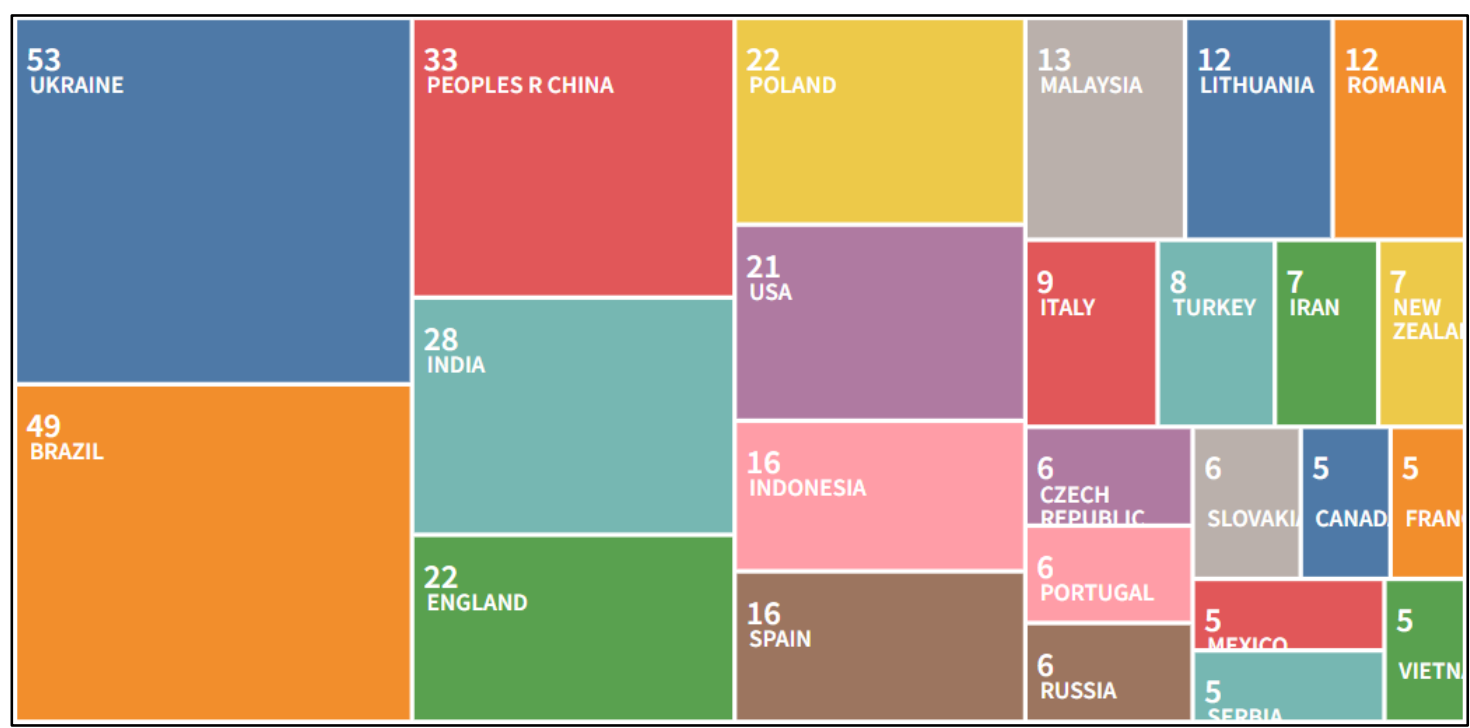

Figure 12: Showing 650 records for Countries/Regions

Source: Web of Science $(2021)^{4}$

\footnotetext{
${ }^{3}$ Web of Science (2021). Citation report for 650 resultsfrom Web of Science Core Collection. Avaliable in: Analyze Results (capes.gov.br). Access in: 08/01/2021

${ }^{4}$ Web of Science (2021). Citation report for 650 resultsfrom Web of Science Core Collection. Avaliable in: Analyze Results (capes.gov.br). Access in: 08/01/2021
} 
INDEPENDENT JOURNAL OF MANAGEMENT \& PRODUCTION (IJM\&P)

http://www.ijmp.jor.br

v. 12, n. 7, September-October 2021

ISSN: 2236-269X

DOI: 10.14807/ijmp.v12i7.1452

Figure 13 presents the data on the institutions from which the access to our journal came, showing only the 25 institutions that most accessed.

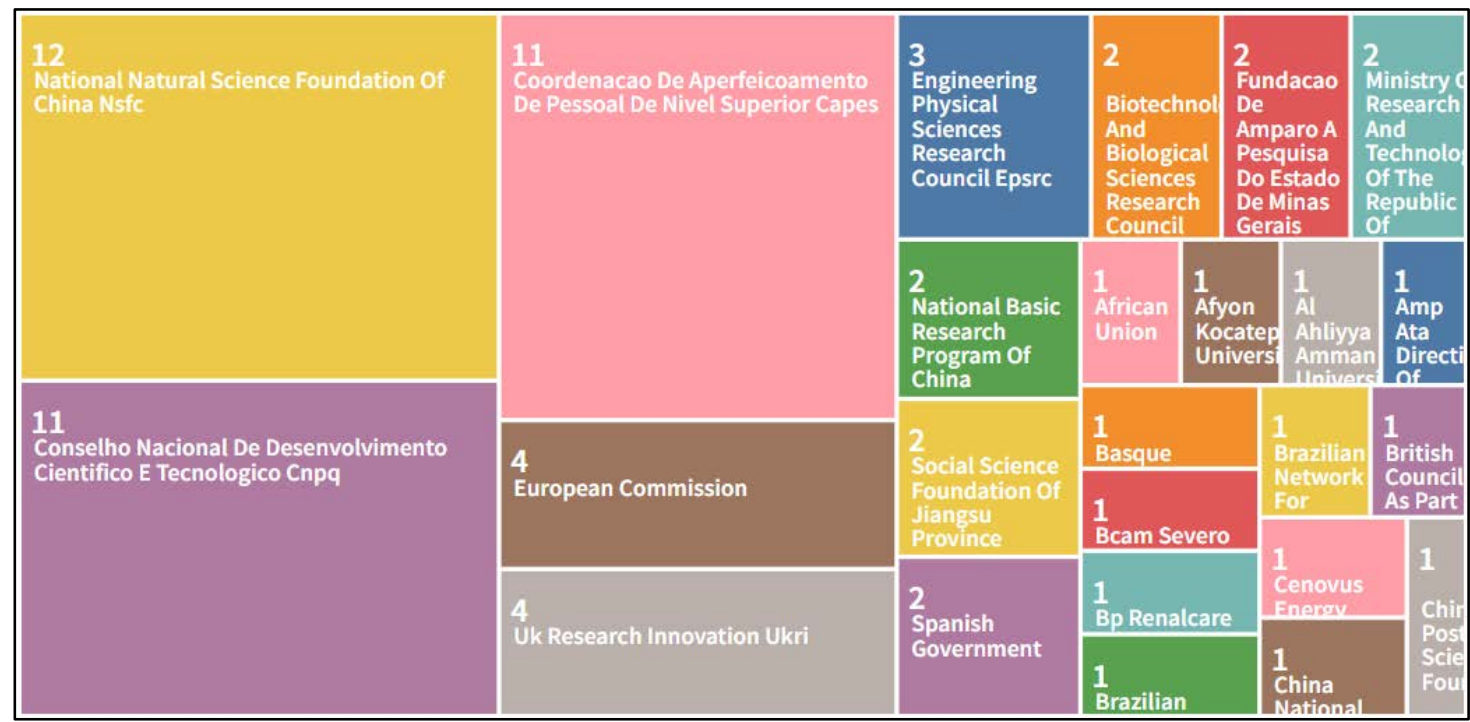

Figure 13: Showing 650 records for Organizations-Enhanced Source: Web of Science $(2021)^{5}$

We appreciate the intense participation of all colleagues, which has made our journal become a place of wide dissemination of knowledge.

The following content will be presented with the titles, authors and the pages of all of the articles published in this edition issue.

Editorial Volume 12, Issue 7 (2007-2016)

Paulo Cesar Chagas Rodrigues

DOI: http://dx.doi.org/10.14807/ijmp.v12i5.1452

Understanding the consumer empowerment in health service (1627-1646)

Megawati Simanjuntak, Riesti Yuja Tesiana

DOI: dx.doi.org/10.14807/ijmp.v12i7.1394

QC-story as cost management support tool application and evaluation in a clothing industry (1647-1665)

Alan Tiago Sanjuliano

DOI: dx.doi.org/10.14807/ijmp.v12i7.1448

Identification of the behavioral criteria of dairy cattle on the basis of electronic imaging (1666-1674)

Ines Jemmali, Najeh Lakhoua

DOI: dx.doi.org/10.14807/ijmp.v12i7.1355

\footnotetext{
${ }^{5}$ Web of Science (2021). Citation report for 525 results from Web of Science Core Collection. Avaliable in: Analyze Results (capes.gov.br). Access in: 08/01/2021 
INDEPENDENT JOURNAL OF MANAGEMENT \& PRODUCTION (IJM\&P)

http://www.ijmp.jor.br

V. 12, n. 7, September-October 2021

ISSN: 2236-269X

DOI: 10.14807/ijmp.v12i7.1452

Economic growth or development: the validity of the theories of Celso Furtado and ECLAC on the Brazilian reality (1675-1696)

Juan Arturo Castañeda-Ayarza, Davi de Pinho Spilleir, Douglas Silva Guimarães

DOI: $\mathbf{d x . d o i . o r g / 1 0 . 1 4 8 0 7 / i j m p . v 1 2 i 7 . 1 4 5 9}$

The effect on pricing strategies in the process of strategic decision making in view of cost of produced goods (1697-1719)

Syed Mohammad Faisal, Ahmad Khalid Khan, 0, 0

DOI: dx.doi.org/10.14807/ijmp.v12i7.1447

What Indian working class is saying about the COVID-19 pandemic: concerns and reactions (1720-1738)

Samant Shant Priya, Sushil Kumar Dixit

DOI: dx.doi.org/10.14807/ijmp.v12i7.1460

Performance enhancement of numerical approaches for scheduling problem on machine single (1739-1750)

Omar Selt, 0

DOI: dx.doi.org/10.14807/ijmp.v12i7.1029

Work interference with family and turnover intentions in Pakistani banks: the role of psychological breach (1751-1773)

Sumaiya Syed, Salman Bashir Memon, Abdul Samad, 0, 0

DOI: dx.doi.org/10.14807/ijmp.v12i7.1454

A single server Markovian queuing system with limited buffer and reverse balking (17741784)

GIRIN SAIKIA, AMIT CHOUDHURY

DOI: dx.doi.org/10.14807/ijmp.v12i7.1471

Contributions of interpersonal conflict management on performance of government hospitals in Nigeria (1785-1807)

Kelechi Johnmary Ani, CHIGOZIE ONU, IJEOMA GENEVIEVE ANIKELECHI

DOI: dx.doi.org/10.14807/ijmp.v12i7.1457

Partnership success factors: overcoming cultural misfit between Tunisian SMEs and their french partners (1808-1835)

Hanen Khanchel

DOI: dx.doi.org/10.14807/ijmp.v12i7.1441

An evaluation of nigerian timber production and forest reserves: focus on economic implications of food security, 1981 - 2014 (1836-1862)

KELECHI JOHNMARY ANI

DOI: dx.doi.org/10.14807/ijmp.v12i7.1456

Challenges of education in LICS (1863-1874)

Branislav Mitić, Armand Faganel, Maša Mitić, 0

DOI: dx.doi.org/10.14807/ijmp.v12i7.1478

[https://creativecommons.org/licenses/by-nc-sa/4.0/legalcode]

Licensed under a Creative Commons Attribution 4.0 United States License 
INDEPENDENT JOURNAL OF MANAGEMENT \& PRODUCTION (IJM\&P)

http://www.ijmp.jor.br

V. 12, n. 7, September-October 2021

ISSN: 2236-269X

DOI: 10.14807/ijmp.v12i7.1452

Identifying the factors affecting the strategic planning in local organizations for designing a structural model (1875-1900)

Behzad Souki, Reza Najaf Beigi, Karamullah Daneshfard

DOI: dx.doi.org/10.14807/ijmp.v12i7.1282

A systematic review on education 4.0 using social media platform (1901-1918)

Rinku Sanjeev

DOI: dx.doi.org/10.14807/ijmp.v12i7.1438

Impact of corporate governance on bank profitability - post reforms by RBI and SEBI (1919-1934)

Riya Anil Rai

DOI: dx.doi.org/10.14807/ijmp.v12i7.1473

Comparative analysis of the TODIM method adherence to prospect theory (1935-1947)

Alexandre Leoneti, Luiz Flávio Autran Monteiro Gomes, 0

DOI: dx.doi.org/10.14807/ijmp.v12i7.1468

Family in contemporary society (1948-1961)

Branislav Mitić, Armand Faganel, Maša Mitić

DOI: dx.doi.org/10.14807/ijmp.v12i7.1477

Role of employer branding in enhancing the talent management strategies: applied study at commercial banks of Jordan (1962-1983)

Atif Badri Al-Qura'an, 0, 0

DOI: dx.doi.org/10.14807/ijmp.v12i7.1449

Settings elaboration of opportunity study necessary to provide public transport services on the administrative territory of the municipality Tîrgu-Mureş (1984-2006)

Relly Victoria Virgil Petrescu

DOI: dx.doi.org/10.14807/ijmp.v12i7.899

October 1, 2021

Prof. Dr. Paulo Cesar Chagas Rodrigues

Chief Editor 